Simonok V.P., Doctor of Philology, Professor, Head of Foreign Languages Department № 1 Yasroslav Mudryi National Law University

\author{
Zelinska O.I., \\ Candidate of Philology, Associate Professor, \\ Associate Professor of Foreign Languages Department № 1 \\ Yasroslav Mudryi National Law University
}

\title{
CONCEPTUAL CATEGORIES APPREHENSION THROUGH BORROWINGS INTO THE UKRAINIAN LANGUAGE
}

\begin{abstract}
Summary. The lingual worldview forms not only throughout the history of a nation and is peculiar to some language but also around certain basic concepts which are general for several or all languages. The development of the lingual worldview includes the transmission of lexical units from one language to the other to name the objects or phenomena which are new or need changes in the wording. The issues of the worldview, national specifics of a language, role of lingual borrowings in the worldview development have interested researchers over the past two centuries but still have not lost their topicality. The concept of worldview in both conceptual and in purely linguistic terms needs further elaboration. The loanwords influence the conceptualization of the worldview, facilitate its development, expand the language lexicon, and deepen the semantic content of words. The article concentrates on the analysis of some philosophical aspects of the worldview development and the role of borrowings in the Ukrainian language worldview the processes of their gradual alignment and unification in different languages, especially in the part related to the progress in science and technology in several decades. Because of the globalization of the conceptual worldview there is a function of internationalization of certain parts of the lexical composition, which leads to the globalization of the lingual worldview. Thus, the borrowings take an important place in the Ukrainian lingual worldview as the means of expressing universal concepts and phenomena. The constant development of Man and society, languages and lingual worldview, changes due to globalization, faster movement of lexical units from one language to the other one, the role of borrowings in the enrichment of languages and the national worldview require further research. The worldview is characterized by openness and the possibility of replenishment.
\end{abstract}

Key words: lingual worldview, borrowings, loanwords, conceptualization.

The general characteristics of the problem. The lingual worldview is based on the perception, thinking, and cognition of the world with its following reflection. A language arms people with the tools to develop the worldview and determines the rules of thinking and behavior. The process of globalization of the conceptual worldview causes the internationalization of some fields of the lexical content. The historical and political determination of the lingual areas makes the specific character of a nation.

There are two main ways of the lingual worldview development. The first one takes place in the process of acquisition of the new semantic space through the linguistic borrowings. It concerns the new linguistic borrowings and the nominative function. The second way can be described with the technical term 'condensation' that means deepening our knowledge about the conceptual space already existing in the language. It is about the development of synonymic meanings complicated with the additional semantic notions and also the style and stylistic borrowings.

Research and publications analysis. The issues of the worldview, national specifics of a language, role oflingualborrowings in the worldview development have interested researchers over the past two centuries. The conceptual and linguistic meaning of the borrowings which come into a language, their place in the worldview, have been studied in the works of Yu. Karaulov, L. Lysychenko, G. Stepanov, the philosophic aspects and linguistic aspects of the worldview development were also researched by the representatives of foreign scientific schools: M. Heidegger, W. Wartburg, J. Larochette. The constant development of the society and languages, the pole of borrowings in the enrichment of languages and the national worldview require further research.

The aim of the article is to analyse the apprehension of philosophical and conceptual aspects of the worldview, its structural elements development through the borrowing into the Ukrainian language.

Presentation of the research materials. The worldview forms around certain basic concepts. Yu. Karaulov [1, p. 12], the whole Universum can be divided into three great parts: 1) Universe; 2) Man; 3) Man and Universe. Every group mentioned above can also be divided into smaller parts containing different amount of units. The fragments of the lingual worldview are different in their dynamics including the different ability to accept elements of foreign languages that is why the problem of lexical borrowing is considered regarding their place in the Ukrainian lingual worldview.

The characteristics of Man and the anthropologic aspects become especially important in the study of worldview because they concentrate on the special human features, mankind existence, the relations of people with the environment, and the world living conditions. The lexical borrowings are usually connected with some parts of the Ukrainian worldview, i.e. the names of different types of social and labour activities of people. The analysis of the borrowed lexical units shows the opposition of the notions 'physical - spiritual', 'natural - artificial', 'inherited - gained in the lifetime'. This opposition is essential for the study of human 
nature, since English, French and German lexical borrowings in the Ukrainian language associated with other pairs of oppositions allow deeper understanding of the physical, psychic, and spiritual nature of people.

The integral part of the doctrine of Man is the knowledge of the Universe. The borrowed lexical units from the Part named the 'Universe' mostly have nominative functions. The concept 'Universe' has the specific historical content, which is determined by the state and level of culture, science, technology, social relations, nature. According to the German philosopher M. Heidegger, "the world is the process of human existence and penetration into the transcendental (out of the boundaries of ultimate existence) state of human being" [2, p. 107]. The concept of 'World' covers the natural and artificial nature, social relations, spiritual world of Man, ways and products of spiritual creativity. V. Wartburg proposes a postulate that the whole picture of the world in the form it exists in an individual mind and in the entire lingual community, organically and without lacunas can be divided from above, from the whole to small fields, and within the fields the semantic spheres of individual words also interlock tightly [3, p. 626].

One of the issues that has to be clarified is the meaning of the concept 'Reality' that we understand it as the world that is expressed in the language. For example, J. Larochette writes on this point, "When a language is considered to be the system of reality representation, then there is no need to clarify that the reality is not understood in ontological sense: this term is understood as everything people can speak about; all classes of objects, existing and non-existent, fictitious, which can be distinguished and imagined (in this case it refers to as "immediate reality"); in addition, all the "objects" that can be comprehended by the mind and which can be so abstract that they cannot be imagined (in this case, it is called "mediated reality"), in this case the term "object" is used in the broad sense which means not only things, features, processes, but also intellectual and emotional qualities. All the mentioned above things taken together represent the view of the world (une représentation du monde), the representation of the whole reality [4, p. 177-178].

Yu. Karaulov considers several concepts concerning worldview: some of them put the concept of God on the first place and that fact reflects the outlook which is associated with religious traditions. Objectively, the central place belongs to the concept of Man and from that scheme following classification can be concluded: Man who is in the center of the world of things and opposes it, divides this world into some homogeneous zones, distinguishing, for example, the living beings, devoid of reason, and on the other hand, the society of human beings, where Man is set off as an individual. If the special characteristic of this scheme is its anthropological orientation, then other researchers offer the "lexical cone" where the vertex is all that is significant from the standpoint of a person who feels indifferent if the object in front of him or her is a person or a stone. Both objects in his scheme represent "something" [5, p. 45-52].

In recent years, with overcoming the one-sided structuralism and returning the attention to such problems as "the People and language", "Man and language" in linguistics, there is a tendency to draw the balance between different aspects of language learning and returning to the problems related to the people and a person, in particular to the question of the national special characteristics of the language.

The national characteristics of the language are determined, first of all, by the internal form of a language, it can be observed at the level of words and fields. When the broad semantic zones formed by the whole complexes of fields (or fragments of the worldview) are compared, the gaps in one language are found in comparison with the other language where they are absent [6, p. 298-300].

Yu. Karaulov considers the component analysis to be "one of the most widely used and most effective linguistic methods" $[1, \mathrm{p} .11]$. The purpose of such analysis is not only the distribution into components, but the search for the place and meaning.

The concept of worldview in both conceptual and in purely linguistic terms needs further elaboration. The word itself is not a direct reflection it acts as a means of expression. It acts as the means of reflection in the field composed of words that are determined historically, socially and individually. National characteristics of a language are based on historical and political conditions. According to G. Melnikov, "the human psyche is a structural dynamic predictive model of external activity. The majority of the units of this model consist of concrete images the reflections of individual denotations (phenomena and objects) a person has to deal with. In addition to these individual structural models the 'generalizations' are formed in the consciousness, they are independent abstract units that are structural models of classes of denotations. Thus, taking into account the virtually limitless number of individual conceptual units in the consciousness of each person, the set of abstractions sequestered by the relevant features of a certain type, all people for whom this type of characteristic is relevant, quite stable and has a fairly close composition" [7, p. 26].

The Borrowings from foreign languages have played the significant role in the Ukrainian worldview development. As it was mentioned, the whole Universum is divided into 3 major sections: 1) the Universe; 2) Man; 3) Man and the Universe. Each of these sections has its own groups.

Thus, Section I the 'Universe' is divided into 4 groups: 1) Sky and Celestial Bodies; 2) the Earth; 3) Wildlife; 4) Plant World. The observation of celestial phenomena belongs to the oldest human interests. The Anglicism квазари (the quasars), two French borrowings гало, зеніт (halo, zenith) belong to this subgroup but there are no German borrowing. This subgroup is represented by scientific narrow-terminological names. The borrowed vocabulary is presented in almost all fragments of the section 'Universe', having mainly nominative function.

Section II - 'Man' has the following groups: 1) Man as a Living Being; 2) Man as a Social Being; 3) Social Institutions and Relationships. In the Section 'Man', a large number of borrowings are found in the fragments of the worldview associated with various types of social and work activities but less borrowed units are traced in the fragments associated with its natural features of people. These fragments of the worldview have the developed system of the Ukrainian names belonging to the Proto-Slavic heritage. In the political sphere of the Ukrainian worldview there are names of historical realities that perform the nominative historical function, for example: бланкіст (blanquist), вандеїст (vandeist), деїсm, (deist), друїд (druid), such names as масон (masons), (нео) найист (neo-Nazis) and (нео) фашист (neo-fascists) are still in use nowadays.

A lot of borrowings have hyper- and hyponimic relations for example: сеньйор - васал (senior - vassal), офіцер - солдат (officer-soldier). Some names come into synonymous relationship, for example: інфант - прини (infant - prince, аудитор - ревізор (auditor - inspector). The following lexical components have 
function of the internationalization: департамент (department), кабінет міністрів (Cabinet of Ministers), комітет (committee), парламент (parliament), президія (presidium). The nominativeexotic function is performed by the names, інфант (infant), електорат (electorate). The names of бакалавр (bachelor), бізнесмен (businessman), губернатор (governor), кавалер (cavalier), кредитор (creditor), махістр (master), маестро (maestro), мер (mayor) came beyond the terminology.

There are the following groups in Section III "Man and the Universe" - 1) A priori; 2) Science and Technology. Each of these groups is divided into smaller ones. The fragments of the lingual worldview differ in dynamics, including the different ability to absorb elements of foreign languages, because of which the problem of lexical borrowing is considered in connection with their place in the Ukrainian worldview.

L. Lysychenko, analyzing the ways of the world-view development, notes that this development takes place in two main ways. The first way is the expansion of the worldview in the process of widening the semantic space, which is inherent for the borrowings. The second one is the consolidation of the worldview, which arises in the process of deepening our knowledge of the conceptual space existing in the language. [8, p. 4-5].

The first way mentioned in this study is associated with the process of borrowing of new words and with the nominative function. The second one is connected with the emergence of the synonymous values, complicated by additional semantic features, and the borrowings with stylistic means.

The characteristics of a person or the anthropological aspect acquires the special value in connection with the study of the worldview, because it makes the special features of man and his / her being, the relationship between man and the world, the conditions of the existence in this world more significant. These signs are reflected in the system of names, which demonstrate all the diversity of human interaction with the environment. In this case, the main continuum of names of persons belongs to the lexical composition, which significant part consists of borrowings. As it was already noted, the borrowed vocabulary, as a rule, is connected with a certain part of the Ukrainian worldview, namely, with the names of the various types of the phenomena of social and labour activity of people. This category includes the words that denote a person in the multilateral relations with other people, with society - "with its various institutions, all spheres of mental and practical activity of a person, in all physical, mental, ethical and moral norms" [9, p. 65].

The borrowed lexical units allow tracing not only the opposition "physical - spiritual", "natural - artificial", "inherited - acquired during life", but also the most generalized opposition to the features caused by the nature of man - physical, natural, social, spiritual, special. This opposition is essential for the study of human nature, since English, French and German lexical borrowings in the Ukrainian language associated with other pairs of oppositions allow deeper understanding of the physical, psychic, and spiritual nature of man.

The part of the worldview 'Man and the Universe' covers two groups: 'A Priori' and 'Science and Technology'. The group 'A Priori' can be divided into seven subgroups: 1) Genesis. 2) Quality and Condition. 3) Relations. 4) Number and Quantity. 5) Space and Time. 6) Movement. 7) Changes.

The subgroup 'Being' covers both material and spiritual existence. Being is what exists: matter, things, properties, links, and relations. The ideas, theories, hypotheses, fantasy, tales, myths exist in the form of spiritual reality. Being is the general basis for the practical and active cognition of the world by Man. To have any properties the thing first of all should exist. The major categories of 'Being' are existence and reality. This subgroup includes the following borrowed names: антецедент (antecedent), екзистенціалізм (existentialism), індивідуалізація (individualization), субстаниія (substance).

In the objective world there is a variety of relations: social, main and secondary, separate, individual and general, organic and inorganic, logical, and others. Everything that exists is related to other existing things, and these relations are the truth of all existence. The content of the category of relations is the interdependence of things (the elements of a particular system, as well as their relative stability and independence). The subgroup "Relations" includes the following borrowing: English: антагонізм (antagonism), елітність (elitism); French: група (group), клас (class).

The Universe is in a continuous motion to its new states. In every living system there are constant internal processes associated with the pulsation of energy, information, consumption, processing and assimilation. The social systems exist through the exchange of information, human activities, and the interaction of various components of the social organism. The lexical subgroup 'Movement' is represented by the borrowings: динаміка (dynamics), еволюиія (evolution). The subgroup 'Changes' covers such borrowings as: вегетаиія (vegetation), генерація (generation). The second group of the section 'Man and the Universe' includes the vocabulary concerning 'Science and Technology'. However, in this case the classification is complicated because 'Technology' covers a large number of phenomena and artifacts that are related to the activity of people and arise from their experience. Since the scientific activity has largely international and global character the worldview is influenced by international terms, which is why it contains a large number of borrowings.

The XXI century is characterized as the age of technology, atomic and space explorations, computerization, robotic and genetic engineering that is associated with the problem of assessing the phenomenon of technology in the development of modern civilization. The progress of technology allows overcoming the fatal diseases, resolution of the conflict situations in society, and providing the dynamic development of public infrastructure. The pessimistic evaluation is called technophobia that means the horror of technology and its consequences for humanity. Proponents of such assessment believe that technical development will turn people into the elements of technical devices. The Earth will gradually become unfit for life so the human desire to achieve well-being by means of technology will lead to its degeneration. Proponents of the neutral assessment believe that everything depends on how people apply the technology.

Any classification is conditioned by different factors. This also applies to the classification scheme of the worldview.

The group "Science and Technology" includes a significant number of the borrowed words belonging to the bio-industry: клонування (cloning), генна інженерія (genetic engineering); computer technology (бim bit, інтерфейс interface, монітор monitor, мультимедіa multimedia); nuclear physics; transport; telecommunications. In this subgroup there are a lot of borrowed words which came from ancient languages or were created on their basis. 
The division of the language into separate constituents is controversial and imperfect, which means that the words of one circle of function often fall into different parts of the worldview or are united in one part, although they differ in essential features. There are certain terms in the analyzed subgroup. The terminological units are characterized not only as the correlation with certain reality, but also depend on the place in the terminological system. Part of the terminology is located on the periphery of the lingual world-view, creating a certain layer, which constantly interacts with the nuclear part. For example, with the development of computer technology, terminology gradually moved from the periphery to the nucleus part. These words have the nominative and terminological function. The terms can penetrate into the bulk of the lingual image, not only as the nominative meaning but also the derivatives. The terminology of each science is the certain sign system. In contrast to the long-borrowed vocabulary which organically intertwines with the language system and interacts with it the terminology is established largely by representatives of a science at their choice.

Conclusions. Since the lingual worldview is heterogeneous in the composition of words, concepts and phenomena, and it is also heterogeneous in the terms of the time of occurrence of certain phenomena in the conceptual view and, respectively, the time of their nomination, borrowings are presented differently in the different parts of the lingual worldview: the most receptive ones are those parts of the lingual worldview that characterize Man and society. The borrowings have various functions: nominative-historical, nominative-explanatory, and the function of internationalization of the lexical composition. Some words went beyond narrow terminological vocabulary and belong to the colloquial style. These borrowing are characterized by hyper- and hyponymic as well as synonymous relations.

As the result of contacts between ethnic groups and the experience exchange, the conceptual picture of the world in the Ukrainian ethnic consciousness develops gradually which requires the appropriate expansion (increase in number) or deepening (semantic content) of words, including those one that come into the language through borrowing. The result of these processes is the gradual alignment and unification of the worldview of different languages, especially in the part related to the progress in science and technology in several decades.

Thus, the borrowings have the important place in the Ukrainian lingual worldview as the means of expressing universal concepts and phenomena. They do not constitute the separate subsystem, but are components of all fragments of the language. The borrowed words cannot look alien in the recipient language worldview for long.

The thesaurus interpretation suggests that the fragments of the lingual worldview, besides having a certain stable structure, are characterized by openness and the possibility of replenishment through including the borrowed words.

\section{References:}

1. Karaulov, Yu. Linguistic Construction and Thesaurus of the Literary Language. Moscow : Science, 1981.

2. Heidegger, M. The Time of Worldview. New Technocratic Wave, 2011. URL : https://plato.stanford.edu/entries/heidegger/.
3. Wartburg, W. Einführung in Problematik und Methodik der Sprachwissenschaft. Tübingen, 1962.

4. Larochette, J. La représentation de la réalité. Folia linguistica, Vol. VI., items 1-2, 2009. URL : https://www.degruyter.com/view/j/ flin.1973.6.issue-1-2/flin.1973.6.1-2.177/flin.1973.6.1-2.177. $\mathrm{xml}$ llang=en.

5. Karaulov, Yu. General and Russian Ideography. Moscow : Science, 1976.

6. Stepanov, Yu. Methods and Principles of Modern Linguistics. Moscow : Science, 1975. URL : https://uploads.philology.by/logo/ stepanov.pdf.

7. Melnikov, G. Types of Signifiers of Language Signs and their Determinants. The Issues of Semiotics. Moscow : Science, 1974.

8. Lisichenko, L. The Conceptual and Language Worldview and their Interaction. Semantics and Pragmatics of Language Units. Collection of research papers. Kharkiv : G.S. Skovoroda KhSPI, 1991. P. 3-9.

Сімонок В., Зелінська О. Сприйняття концептуальних категорій через запозичення в украйнській мові

Анотація. Людина формує свою картину світу за посередництвом мови. Мовна картина світу грунтується на сприйнятті, мисленні та пізнанні світу 3 подальшим його відображенням. Питання розвитку мовної картини світу, національних особливостей мов, ролі запозичень у розвитку мовної картини світу цікавило дослідників протягом останніх двох століть, але воно не втратило своєї актуальності дотепер через постійні зміни, що відбуваються iз самою Людиною, суспільством, матеріальним середовищем, що їі оточує, і особливо через суспільний і науково-технічний прогрес, що постійно пришвидшується.

Розвиток мовної картини світу передбачає переміщення лексичних одиниць 3 інших мов, щоб називати предмети або явища, які є новими або потребують іншої форми вираження. Запозичення впливають на концептуалізацію картини світу, сприяють їі розвитку, розширюють лексикон, поглиблюють семантичний зміст слів. Розвиток мовної картини світу відбувається двома основними способами: шляхом розширення картини світу у процесі освоєння нового семантичного простору, що властиве запозиченням, а також через ущільнення мовної картини світу, яке виникає в процесі поглиблення наших знань про вже освоєний мовою концептуальний простір. У статті проведений аналіз певних філософських аспектів розвитку мовної картини світу та ролі запозичень в україномовній картині світу; приділено увагу процесу поступового вбудовування мовних одиниць у мовленнєве середовище, а також їх уніфікації в різних мовах, особливо, коли це стосується явищ науково-технічного прогресу та суспільного розвитку. Запозичення відіграють істотну роль у називанні характерних рис людей або їхньої діяльності, їхнього місця в суспільстві, що постійно змінюється, суспільних явищ, результатів наукових досліджень. У статті досліджено роль запозичених лексичних одиниць у процесі утворення термінів. Отже, запозичення займають важливе місце в українській мовній картині світу як засоби вираження універсальних концептів і явищ. Безперервний розвиток суспільства, Людини, зміни у сприйнятті сучасної картини світу, процеси глобалізації сприяють утворенню нових лексичних одиниць, їх швидкому переміщенню з однієї мови до іншої, а тому потребують подальшого наукового аналізу.

Ключові слова: мовна картина світу, запозичення, концептуалізація, номінативна функція. 